\title{
Research on Financing Mode of SMES Based on Internet Finance
}

\author{
Zuguo Yin
}

Jiangxi Vocational College of Ahead Software, Jiangxi, Nanchang, 330000

Keywords: Internet Finance, SMES, Financing

\begin{abstract}
With the development of China's socialist market economy, SMES are playing an increasingly important role in driving economic development and promoting urbanization. However, in recent years, the financing difficulties of SMES have not been solved, and the financing difficulties of SMES have become the bottleneck of their development and growth. The development of Internet finance provides a new mode of financing for SMES. In the national economy, SMES are in a particularly important position. However, the financing difficulties of SMES restrict the development of SMES. The emergence of Internet financial model has opened up a new way for SMES to finance. Based on the analysis of the financing difficulties of small and medium-sized enterprises, on the basis of starting from the advantages of the Internet financing the new financial model analyzes the feasibility of Internet finance in promoting small and medium-sized enterprise financing, and further discussed in using the Internet in our country financial solve the problem of small and medium-sized enterprise financing problems and suggestions in the process.
\end{abstract}

\section{Related Concepts of Internet Finance}

Definition of Internet Finance. We should make clear that there is no essential difference between Internet finance and traditional finance. The essence of Internet finance is about the flow and distribution of money across time and space. But financial with the advantages of its technology, the Internet makes money in existing form, distribution, trade, etc have great changes, and in each main body of information about the financial data collection and analysis, on the forms and effects in real life has a huge difference. Internet financial is not traditional easily implemented its business through the Internet, but use the Internet to the big data, cloud computing and intelligent search technology advantage, the traditional financial operation, thus derived from the Internet under the technical support of new financial services. [1]Given the Internet finance is a new form, the form and the possibility of its development is very rich, will change every aspect of people's life, so the Internet financial is the Internet in the broadest sense of the financial, refer to have the characteristics of the Internet financial system. Including but not limited to third-party payment, sales of online financial products, credit evaluation and verification, financial intermediaries, financial e-commerce and other modes.

\section{Existing models of INTERNET Finance.}

1) Internet financial enterprises based on e-commerce platforms.

At present in China, on the vast Internet financial enterprise is Alibaba's small micro enterprise financial group, Ali finance is a typical by e-commerce platform to expand Internet financial companies. The Internet financial institutions developed from the e-commerce platform represented by Alibaba mainly serve SMES on the platform. The enterprise electronic commerce platform management mainly through the Internet, which makes such as Alibaba e-commerce operators can get a lot of on the platform of enterprise management, sales, capital and consumer evaluation information, and these information for financial institutions for small and medium-sized enterprises to provide the most reliable basis was provided for the credit. The enterprise information of e-commerce platform plays the role of credit investigation system in essence, and the enterprise information obtained solves the problem of information asymmetry under the traditional financial model. This is the result of Internet financial institutions mining the value of big data.[2]

2)The P2P mode. 
In essence, $\mathrm{P} 2 \mathrm{P}$ websites are no different from traditional private individual loans, but the change of media platforms has also brought many changes, making more capital circulation possible. First, geographical constraints on both lenders and borrowers have disappeared. As a result of borrowing from the real world into the Internet media platform, lending both sides do not need to be in the same geographic area or have relationships to achieve borrowing, both only need access to the Internet, will be able to realize the matching of supply and demand; Second, information transmission is more efficient. The information transmission of the Internet is real-time. Any information changes between the two parties can be immediately known to the other party on the Internet platform. Third, the price of funds is transparent and unified. The fund provider can see the loan interest rate proposed by all the borrowers on the platform, and the transparency of the fund price will promote the rationalization and unification of the fund price in the platform. However, at present, the biggest problem of $\mathrm{P} 2 \mathrm{P}$ online lending platforms in China is that they are prone to offline lending and become illegal private financing, which is a high pressure line prohibited by the state[2].

3)Crowd funding model.

The crowd funding model is also one of the innovative models derived from the Internet financial model. At present, more successful crowd funding websites in China are like "naming time". Most of the financing on crowd funding websites is based on a certain project, and enterprises need to clearly announce the content of their projects and specific return methods on the website. A big difference between crowd funding and other financing methods is that crowd funding mostly returns with non-capital materials, such as the final products of financing projects.

\section{Financing Status of SMES}

Less Effective Financing Channels. The main financing channels of SMES include: internal financing, commercial credit, borrowing by financial institutions, debt financing and equity financing. But, for now, our country's capital market is not perfect, the financial system has not yet formed a service effectively for many small and medium-sized enterprises to provide financing of capital market, moreover, direct financing channels such as bond and stock markets in our country has set strict access system, small and medium-sized enterprises due to its size, the condition of assets, credit registration problems, so the endogenous financing is limited. For borrowing from financial institutions, commercial Banks generally more tend to economic benefits for those who are good, large scale, large amount of borrowing enterprises to provide financing services, other companies are difficult to get loans from the enterprise. Mainly because of the bank in order to avoid risk, to reduce as far as possible to reduce the probability of bad loans in the process of loan, and small and medium-sized enterprises due to the small scale, weak ability to resist risks, financial system is not sound, and the lack of adequate property to mortgage aspects of reasons, lead to the market risk is bigger, the bank for their own profitability and security considerations, as far as possible to reduce loans to small and medium-sized enterprises.[3]

High Financing Costs. Small and medium-sized enterprises in order to adapt to the vagaries of the market economy environment change and keep its healthy and sustainable development, must keep business flexibility and agility of the change, which will determine the money demand has the characteristics of high frequency, small amount. In order to reduce the risk of lending to SMES, Banks need to organize manpower, material resources and financial resources to investigate the credit rating and financial status of SMES. [3]In general, Banks' review fees, management fees and supervision fees for SMES' loans are 5-8 times higher than those for large enterprises. Banks can compensate for high costs by raising interest rates on loans while ensuring that they can meet their profit targets. High financing cost, on the other hand, also makes the small and medium-sized enterprise debt burden, financial risk is high, companies face the due cannot pay debt interest risk also increased, which increased the degree of small and medium-sized enterprise financing difficulties. And, of course, part of the enterprise to from private financing, private lending relative to bank loan, low requirements, procedure is simple, do not need to provide the mortgage and guarantee, but the folk lending interest rates than bank loan interest rate is much higher, this will no 
doubt increase the enterprise's financing costs. Although private lending to a certain extent, ease the financing difficulties of small and medium-sized enterprises, but because our country folk lending has not form a standardized operation system, private lending remains to be further promoted.

\section{Advantages and Reasons of Internet Financial Model}

Low Cost Advantage. Based on the concept of the Internet financial, the Internet is one of the existed in cyberspace virtualization, network financial activities and related financial products are traded directly online most of the process and handle, do not need to meet capital demanders and providers, significantly reduce the both sides of the assignments and transaction costs. Compared with traditional finance, which must open a large number of physical institutions, Internet finance also saves a lot of investment costs. [4]At the same time, Internet finance USES cloud computing to process data, reducing the processing cost of information. The biggest characteristic of Internet finance is small amount of single loan, short period and simple procedure. Loans with such characteristics are just not welcomed by traditional commercial Banks, and Internet finance makes up for this gap with the advantage of low cost.

Big Data Advantage. Internet financial advantage of big data, cloud computing, mobile payment, search engines and social networks and other advanced technology and powerful data accumulation, advantage analysis and mining, reduced the degree of asymmetric information. The acquisition, processing and use of big data also reflects the personalized characteristics of Internet finance.

The Service Scope is Wide. Compared with traditional financial products, Internet finance covers a wide range of industries and a large number of products. Basically every industries and enterprises may, according to its own characteristics in the field of Internet financial find suits own financial products, improve properly, can be a good service for enterprises, promoting the development of the enterprise, which on the other hand, also promoted the wide application and popularization of the Internet financial.

Diversification Advantage. Internet financial development in China has formed the third-party payment, P2P network platform, large data loan finance, information suggests, financial institutions, financial Internet portal six patterns.[4] Each of these models has its own unique characteristics, and if used properly, it can play a role of four or two thousand pounds for enterprises to promote their better development.

Keep Innovating. The innovative characteristics of Internet finance are determined by its customer-oriented service. The rapid development of information science and technology, contributed to the financial market change alternately, in the face of a variety of customer demand, the Internet financial only take the needs of customers as their driving force of development, continuous innovation, constantly meet customer demand, to gain a foothold in the financial market.

\section{Innovation in Internet Finance and Financing Mode of SMES}

The Mode Among the Crowd Funding. Financing mode refers to the small and medium-sized enterprises using the Internet social network transmission performance, in the form of group purchase and purchase in advance to the public to raise funding pattern. The key features of crowd funding are small amount and large amount, low financing threshold and not only commercial value as the evaluation standard, which opens up a new financing way for SMES. [4]Using the raise pattern, small and medium-sized enterprises on the raised platform to establish a special project web page is introduced to the public project content and methods of specific project returns the public through the financing project and return the understanding, analysis, and judgment, choose the interested in enterprise and project invest or provide financial support.[3] A big difference between the mode of crowd funding and other financing methods is that crowd funding generally returns with some non-capital materials.

E-commerce Platform. Small loan financing model e-commerce platform micro credit financing mode mainly refers to the electric business platform data as the basis, the capital 
requirements of small and medium-sized enterprises in the field of e-commerce analysis, audit, to meet the requirements of small and medium-sized enterprises to provide a financing mode for the loan. Ali small loan is a typical representative of this financing model, mainly through "P2P small loan $+\mathrm{O} 2 \mathrm{O}$ model" for quantitative lending. Ali small loan is mainly based on electric business platform in the trade situation, network users and interactive information, shopping habits and complaints disputes such as the big data cloud computing to real-time calculation, analysis, processing, to establish a database model of small and medium-sized enterprise loan, timely and rapidly extend loans to small and medium-sized enterprises. The flow process can be seen in Fig. 1.

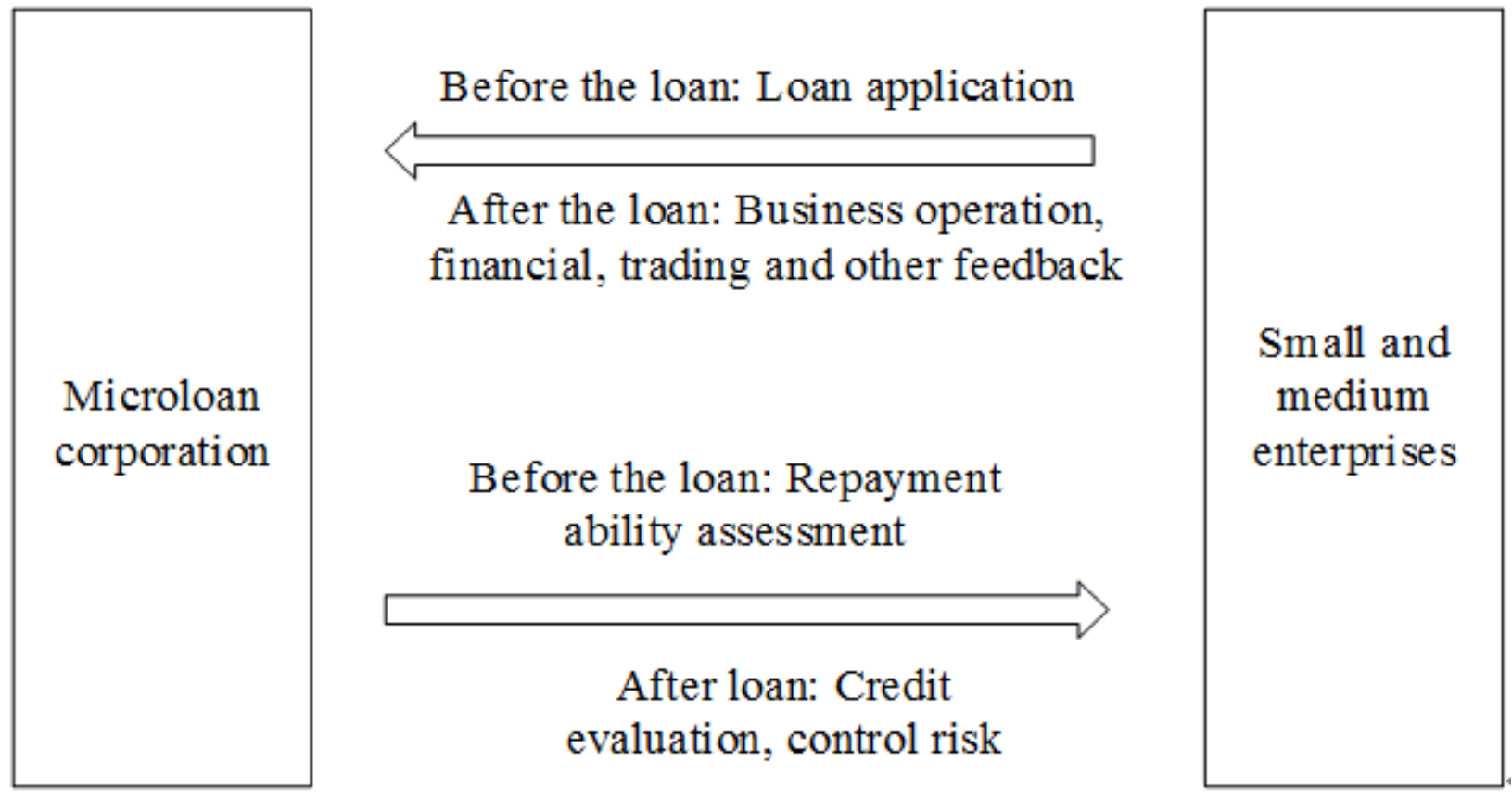

Figure 1. Finite Micro credit financing model flow based on big data

Internet Financial Portal Mode. Internet portal mode refers to the small and medium-sized enterprise use of the Internet financial gateway service platform, the platform of various financial institutions vertical search products for a variety of financial products prices and characteristics of comparative analysis, select a financial institutions to provide appropriate financial services products. The essence of this model is the "search-price" model. In the current numerous Internet financial models, the Internet financial portal model is rapidly rising. Take Rong360, a domestic financial vertical search platform founded in 2011. First, SMES choose to use it as a financial gateway. Second, for the financial products on the financial portal platform for vertical comparison analysis, and then determine to provide matching electronic financial institutions financing credit products, finally, the small and medium-sized enterprises using three-dimensional service system composed of a variety of ways the electronic bank quickly get financial institutions financing. Therefore, 360, also known as the "Chinese consumers and small and medium-sized enterprise financial service search and recommend platform", from a certain extent, help to solve the small and medium-sized enterprises in China, individual operators and consumer loans difficult question. Some small and medium-sized enterprises cannot directly raise funds through the capital market. The funds of small and medium-sized enterprises mainly come from internal financing and borrowing from financial institutions. The flow process can be seen in Fig. 2. 


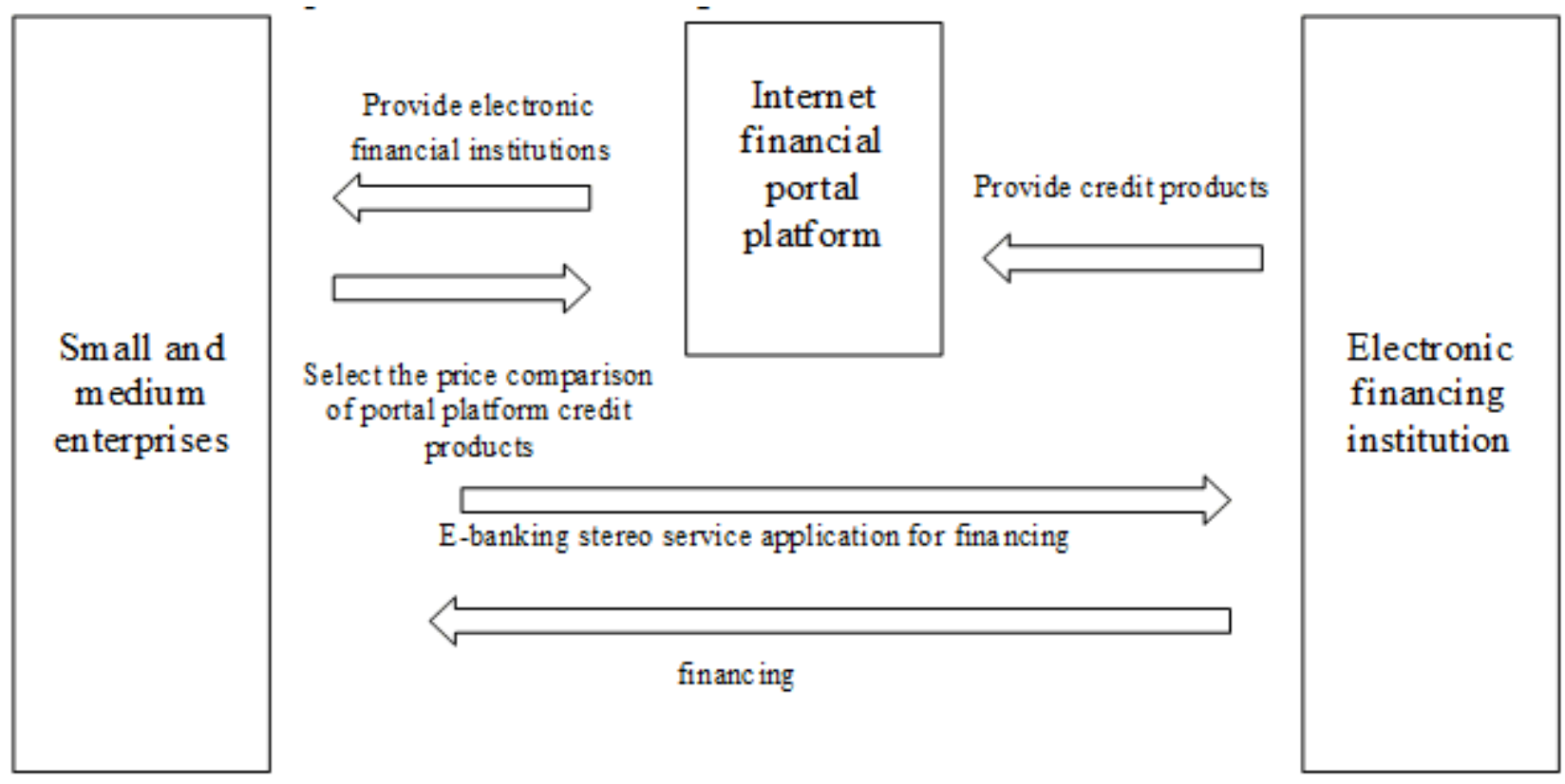

Figure 2.Electronic financial institutions financing model flow

\section{Conclusion}

Internet financial due to its special features and advantages, can well solve the problem of financing of small and medium-sized enterprises, however, the development of the Internet financial challenges facing also be solved, only Internet financial can be healthy and rapid development, under the regulation can better solve the problem of financing of small and medium-sized enterprises. Internet financial characteristics and the characteristics of small and medium-sized enterprise financing needs very anastomosis, the docking of both the biggest problem is the problem of asymmetric information, through various measures to arrange in order to effectively reduce the risk of information asymmetry between investors and issuers, financing for small and medium enterprises to find new and relatively effective financing way, will to a certain extent, solve the problem of small and medium-sized enterprise financing difficulties, also can be used as other types of small and medium-sized enterprises even larger companies via the Internet is a useful reference for financial financing mode.

\section{References}

[1] Wang Z L. The financial strategy research for SME based on the theory Of corporate life cycle[C]//International Conference on Business Management and Electronic Information. IEEE, 2011(1):626+628.

[2] Liang C, Zhi W, Wang S. Notice of RetractionResearch on SME's Financing under Financial Crisis Based on the Perspective of China's Credit Market[C]//International Conference on E-Business and E-Government. 2010(2):5243+5246.

[3] $\mathrm{Hu}$ Y. Research on Financing Model of the Chinese SMEs in Supply Chain Finance[J].2016, $4(5): 235$.

[4] Li H, Huang D. Research on carbon credit financing of SMEs based on game theory[C]// International Conference on Information Management, Innovation Management and Industrial Engineering. 2014(2):356+359.

[5] Yu D, Peng L. When does Inferring Reputation Probability Countervail Temptation in Cooperative Behaviors for the Prisoners' Dilemma Game? [J]. Chaos, Solitons \& Fractals, 2015, 78: $238-244$. 